$(4,12)$. Wyrażona w tym określeniu wielkość i rola słowa Bożego została prżez analizę wielu miejsc Listu do Hebrajczyków lepiej i bardziej szczegółowo ukazana przede wszystkim przez doprowadzenie w syntetycznej części naszych rozważań do ujęcia zagadnienia w aspekcie historii zbawienia.

Rozważając działanie tego Bożego słowa List do Hebrajczyków stawia przed czytelnikiem zawsze aktualne wezwanie: Dziś, jeśli glos Jego usiyszycie, nie zatwardzajcie serc waszych $(3,7)$. W kontekście takiego bowiem wezwania rozumiemy myśl Autora, który przede wszystkim jest duszpasterzem nawolującym do posłuszeństwa. Jeżeli mówi o słowie Boga, to dlatego, aby wyzwolić słowo ludzkiej odpowiedzi.

Kraków

KS. TOMASZ JELONEK

Ks. Jerzy Woźniak CM

\title{
IMPLIKACJE HAJ JAHWE
}

ASPEKTY SOCJOLOGICZNE PRZYSIĘGI HAJ JAHWE

Przysięga haj Jahwe jest wypowiadana przez jednostki, bądź przez grupę społeczną, przez ludzi biednych i bogatych w różnych sytuacjach życiowych. Dlatego możemy mówić o aspekcie socjologicznym tejże przysięgi.

Należy zaznaczyć, że ,każda wypowiedź (akt mówienia) zawiera $\mathrm{w}$ sobie zawsze moment socjalny i jest przez kogoś kierowana do kogoś innego (do słuchacza lub rozmówcy) z wyraźnym celem porozumienia się, wymiany doświadczeń czy wywołania określonych skutków" 1.

Nadto wypada zauważyć, że „dzieło literackie jest faktem społecznym, ponieważ jego twórca (autor) jest członkiem określonej społeczności, żyje w pewnym środowisku, które wpływa kształtująco nie tylko na jego osobiste losy, ale także na jego twórcze (zawodowe) działania i produkt tych działań - utwór literacki ${ }^{2}$. Jak widzimy każde dzieło literackie i każda wypowiedź mają charaktër społeczny.

1 M. Glowiński, - A. Okopień-Sławińska - J. Sławińs ki, Zarys teologii literatury, Warszawa 1972, s. 15.

2 Tamże, s. 17. 
Zapytajmy się: jakie wyznaczniki socjalne posiada dzieło literackie względnie wypowiedź literacka? Za Alberto $\mathrm{Me} \mathrm{m} \mathrm{mi}{ }^{3}$ wyróżniamy następujące wyznaczniki socjalne: autor, dzieło, publiczność. Charakteryzując postawe autora bierzemy pod uwage jego status ekonomiczny, status zawodowy, klasę społeczną, pokolenie literackie. Przy omawianiu dzieła zwracamy uwagę na socjologię gatunków i socjologię tematów, socjologię charakterów i postaci, socjologię stylów. A analizie publiczności zwracamy uwagę na odbiór czytelniczy, więź między dziełem a publicznością, reakcje różnych czytelników, komunikatywność, sukces. Przy omawianiu przysięgi haj Jahwe zwrócimy ùwagę na autora, dzieło, publiczność czyli w tym wypadku na odbiorce.

\section{AUTOR}

A. Status ekonomiczny.

Nadawcy przysięgi haj Jahwe pod względem statusu ekonomicznego czyli możliwości dysponowania środkami materialnymi bardzo poważnie się różnią. Przysięgę wypowiadają królowie, którzy mają do dyspozycji wszelkie środki materialne, aby zrealizować zamierzone cele.

Spotykamy następujące postacie królewskie:

król Dawid - - $1 \operatorname{Sm~20,3;25,34;26,10.~16;~} 2 \operatorname{Sm~4,~9;12,~5:~}$

14,$11 ; 1 \mathrm{Krl} 1,29$.

król Saul - - $1 \operatorname{Sm~} 19,6 ; 28,10 ; 14,39$

król Salomon - - $1 \mathrm{Krl} 2,24$

król Sedecjasz - - Jr 38, 16.

Przysięgę haj Jahwe wypowiadają osoby zasobne w środki materialne:

Obadjahu - urzędnik dworski - $1 \mathrm{Krl} 18,10$

Jonatan - książę, następca tronu - 1 Sm 20, 21

Gedeon - sędzia - Sdz 8, 19

Akisz — wódz ‘ $1 \mathrm{Sm} \mathrm{29,6.}$

Są to ludzie zasobni i zajmujący naczelne stanowiska w swoim narodzie.

Następna grupa to ludzie ubodzy, którzy są uzależnieniu w stosunkach ekonomicznych. Do nich należy:

Eliasz - prorok - $1 \mathrm{Krl} 18,15$

Elizeusz - prorok - $2 \mathrm{Krl} \mathrm{3,14;5,16}$

Jeremiasz - prorok - Jr 5, 2

3 A. Memmi, Problemy socjologíi literatury, w: Wspótczesna teoria badañ literackich za granica, Kraków ${ }^{2} 1976$, t. 3, s. 93nn. 


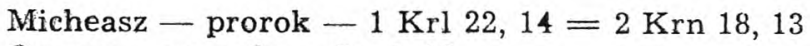

Ozeasz - prorok - Oz. 4, 15

Szunemitka - $2 \operatorname{Krl~4,30}$

wdowa z Sarepty - $1 \mathrm{Krl} \mathrm{17,} 12$

Booz - rolnik - Rut 3,13

Ittaj - wojownik - $2 \mathrm{Sm} \mathrm{15,21}$

Gehazi - sługa - $2 \mathrm{Krl} \mathrm{5,20}$

Abigail - służebnica - $1 \mathrm{Sm} \mathrm{25,26.}$

W kilku wypadkach nadawca nie może mieć związku ze statusem ekonomicznym, gdyż należy do kategorii przekraczającej jakiekolwiek badania ekonomiczne:

Jahwe - Jr 12, 16; 4, 2

Slowo Jahwe - Jr 44, 26

Wyrocznia Jahwe - Jr 16, 14. $15=\operatorname{Jr} 23,7.8$.

Niekiedy nadawca nie jest bliżej określony i dlatego status ekonomiczny nie może być bliżej podany:

lud $-1 \mathrm{Sm} \mathrm{14,45}$

podmiot indywidualny - Ps $18,47=2 \operatorname{Sm~} 22,47$.

Jak widzimy przysięga haj Jahwe jest wypowiadana przez ludzi najbogatszych, królów (Dawid, Saul, Salomon, Sedecjasz), przez ludzi wpływowych (Jonatan, Akisz), przez średniozamożnych (Ozeasz, Jeremiasz, Micheasz, Booz), przez bardzo ubogich (Szunemitka, wdowa z Sarepty, Abigail). Stwierdzamy, że przysięga haj Jahwe ma charakter powszechny i jest wypowiadana niezależnie od statusu ekonomicznego.

B. Status zawodowy.

Nadawcy przysięgi haj Jahwe posiadają różne zawody, powołania życiowe, które zapewniają im w społeczeństwie określoną pozycję społeczną. Spotykamy królów (Dawid, Saul, Sedecjasz, Salomon), wojowników (Jonatan, Akisz, Ittaj), proroków (Eliasz, Elizeusz, Micheasz, Jeremiasz), sędziów (Gedeon), rolników (Booz, wdowa z Sarepty, Szunemitka), służbę, niewolników (Gehazi, Abigail).

Jak widzimy przynależność do różnych zawodów, powolan wskazuje na powszechność stosowania przysięgi haj Jahwe.

C. Klasa spoleczna.

Związek z daną klasą, jak zauważa Alberto M e m m i 4, prowadzi do wyróżnienia przynależności społeczno-ekonomicznej i przynależności ideologicznej. Przynależność społeczno-ekonomiczną można rozpatrywać i badać na podstawie statusu ekonomicznego i zawodo-

1 Tamże, s. 96. 
wego. Stwierdzenie przynależności ideologicznej wymaga wnikliwego studium, gdyż nie zawsze pisarz należący do danej klasy wyraża poglądy swojej klasy. Nadawcy przysięgi haj Jahwe należą do klasy panującej i klasy robotniczej. Do klasy panującej zaliczamy królów (Dawid, Sedecjasz, Salomon, Saul, Obadjahu, Akisz). Do klasy robotniczej zaliczamy: proroka Eliasza, Gedeona, Szunemitke, wdowę z Sarepty, Elizeusza, Jeremiasza, Micheasza, Booza, Ittaja, Gehaziego, Ozeasza, Abigail.

Interesująca jest przynależność Jonatana do klasy panującej. Wydaje się, że ze względu jedynie na pochodzenie i na pretendowanie do korony należal do klasy panującej. Jednakże ze względu na wýznawane poglądy, wyrażone w jego postępowaniu wobec Dawida, ideologicznie nie należał do swojej klasy. Jonatan zawarł przyjaźn z Dawidem, zwykłym pasterzem i zrzekł się tronu ze względu na niego.

\section{DZIEEO}

Przysięga haj Jahwe traktowana jako wypowiedź należy do gatunków literackich znanych w całym starożytnym Wschodzie. Ten gatunek literacki jest ponad klasowy, gdyż jest wypowiedzią religijną stosowaną przez klạsę panującą jak i "robotniczą".

\section{ODBIORCA}

Odbiorcami przysiçgi są osoby należące do różnych klas społecznych. Spotykamy królów: Achab - $1 \mathrm{Krl} \mathrm{17,} \mathrm{1;} \mathrm{Saul} \mathrm{-} 1$ Sm 14,

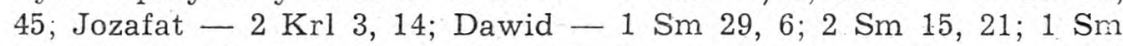
25, 26: 20, 21; ludzi związanych z dworem królewskim: urzędnik

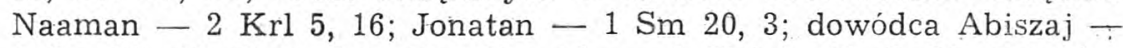
$1 \mathrm{Sm} \mathrm{26,10;} \mathrm{Batszeba,} \mathrm{żona} \mathrm{Dawida} \mathrm{-} 1 \mathrm{Krl} \mathrm{1,} \mathrm{29;} \mathrm{2,} \mathrm{24;} \mathrm{dowódca}$ Obadjahu - $1 \mathrm{Krl} \mathrm{18,15.}$

Następnie spotykamy proroków, żołnierzy i kobiety: proroka Eliasza - $1 \mathrm{Krl} 18,10 ; 17,12 ; 2 \mathrm{Krl}$ 2, 2.4.6; prorok Elizeusz $2 \mathrm{Krl} 4$, 30; prorok Natan - $2 \mathrm{Sm} 12,5$; prorok Jeremiasz - Jr 36, 16; 16, 14. $15=23$, 7. 8; żołnierze Zebach i Salmunna - Sdz 8, 19; Rekab i Baana - $2 \mathrm{Sm} \mathrm{4,} \mathrm{9;} \mathrm{wodzowie} \mathrm{ludu} \mathrm{-} 1 \mathrm{Sm} \mathrm{14,} \mathrm{39;} \mathrm{posłaniec}$ króla Achaba $-2 \mathrm{Krl} 22,14=2 \mathrm{Krn} \mathrm{18,} \mathrm{13;} \mathrm{Gehazi} \mathrm{sługa} \mathrm{Elizeu-}$ sza - $2 \mathrm{Krl} 5,20$. Niewiasty: kobieta z Tekoa - $2 \operatorname{Sm} 14,11$; wróżka z Endor - $1 \mathrm{Sm} \mathrm{28,10;} \mathrm{Kalebitka} \mathrm{Abigail} \mathrm{-} 1$ Sm 25, 34.

Oprócz odbiorcy jednostkowego przedmiotem przysięgi haj Jahwe jest odbiorca społeczny. Do tego typu odbiorcy kolektywnego należy: naród izraelski - Jr 4,2;23, 7. 8; Oz 4; 15; ludy wrogie Izraelowi - Jr 12,16; dwaj żołnierze - Zebach i.Salmunna - Sdz 
8, 19; Rekab i Baana - $2 \operatorname{Sm~4,~9;~mieszkańcy~Jerozolimy~--~Jr~5,~} 2$. W jednym wypadku odbiorca utożsamia się z nadawcą - Gehazi $2 \mathrm{Krl} \mathrm{15,} 20$.

Odbiorcami przysiegi haj Jahwe są nie tylko osoby uznające Jahwe jako Boga nad Izraelem (np. Dawid, Eliasz, Elizeusz, Jeremiasz), ale również osoby nie uznające kultu Jahwe (kobieta z Tekoa, Naaman, ludy wrogie Izraelowi, Kalebitka Abigail, Obadjahu).

Jak widzimy $z$ przeprowadzonych analiz przysiega haj Jahwe jest związana $z$ człowiekiem, $z$ jego sytuacją egzystencjalną i zapewnia skuteczne działanie nadawcy.

\section{STOSUNKI SYNTAGMATYCZNE HAJ JAHWE}

Związki syntagmatyczne są terminem twórcy językoznawstwa strukturalnego Ferdynanda de S a us u re'a. Podstawowym pojęciem jest tutaj syntagma. F. de Saussure tak ją określa „Z jednej strony w każdej wypowiedzi wyrazy nawiązują między sobą na mocy swego połaczenia stosunki oparte na charakterze liniowym języka, który wyklucza możliwośé wymówienia elementów. Te polączenia, dla których oparciem jest przestrzeń, możemy nazwać syntagmami. Syntagma składa się więc zawsze z dwóch lub więcej jednostek następujących po sobie" "5. Syntagma jest również określana jako związek syntagmatyczny ${ }^{6}$.

Natomiast stosunki syntagmatyczne - również są terminem F. de Saussure'a - są to stosunki, w jakich pozostaje dany element ciągu wypowiedzeniowego do swego otoczenia poprzedzającego i następującego. Poszczególne elementy wypowiedzenia tworzą grupy składniowe tzw. syntagmy zawierające dwie lub więcej jednostek wypowiedzeniowych Każdy człon syntagmy pełni określoną funkcję składniową, która wynika ze stosunku, jaki zachodzi między nim a członem poprzedzającym względnie obu razem. Pojęcie stosunków syntagmatycznych dotyczy nie tylko grup wyrazowych dowolnej objętości, ale również i wyrazów motywowanch i ułożonych ${ }^{\top}$.

Między wyrażeniami tworzącymi związki i stosunki syntagmatyczne zachodzą związki uprzedniości i następstwa ${ }^{8}$. Ze związków tych wynikają takie właściwości wyrażeń, jak ich prepozycja lub postpozycja względem innych wyrażeń $\mathrm{z}$ ewentualnym podziałem na prepozycję i postpozycję bezpośrednią (styczność) lub pośrednią

5 F. de Saussure, Kurs językoznawstwa ogólnego, Warszawa 1961, s. 131 .

${ }_{6}$ Z. Goląb- A. Heinz-K. Polański, Stownik terminologii językoznawczej, Warszawa 1970, s. 556.

7 Jak wyżej.

8 S. Ka r ol a k, Zagadnienia składni ogólnej, Warszawa 1972, s. 6. 
(brak styczności) w ciągach syntagmatycznych składających się z większej od dwóch liczby wyrażen prostych. Bezpośredniość prepozycji i postpozycji może ponadto być stała lub niestała.

Stała bezpośrednia prepozycja \| postpozycja czyli inaczej nieodłączalność jednych wyrażeń od innych jest wtedy, kiedy dwa wyrażenia są w styczności niezależnie od liczby wyrażeń prostych składających się na dane wyrażenie złożone. Niestała czyli odłączalność jednych wyrażeń od innych jest wtedy, kiedy dane dwa wyrażenia są w styczności tylko w wyrażeniach składających się z dwóch wyrażeń, a przestają być w styczności w wyrażeniach złożonych - z większej od dwóch liczby wyrażeń prostych.

\section{ZWIĄZEK SYNTAGMATYCZNY HAJ JAHWE}

Związek syntagmatyczny haj Jahwe jest zdaniem nominalnym o szyku inwersyjnym, gdzie podmiotem jest Jahwe a orzecznikiem przymiotnik odsłowny haj, który występuje w funkcji czasownika $\mathrm{w}$ przysieggach haj Jahwe $\mathrm{z}$ kontekstem boalistycznym oraz $\mathrm{w}$ funkcji rzeczownika w przysięgach haj Jahwe z kontekstem życia codziennego. Haj wobec Jahwe występuje trzydzieści trzy razy w prepozycji bezpośredniej a jeden raz w Jr 44, 26 - haj ladōnāj Jahwe w prepozycji pośredniej. Natomiast Jahwe wobec haj występuje trzydzieści trzy razy w postpozycji bezpośredniej, a jeden raz w Jr 44, $26 \mathrm{w}$ postpozycji pośredniej.

\section{STOSUNKI SYNTAGMITYCZNE.}

Przysięga haj Jahwe pozostaje w konkurencji z partykułami wyodrębniającymi i innymi wyrażeniami.

Przysięgi negatywne

A. Partykuły wyodrębniajace.

Partykuła lim występuje $\mathrm{w}$ prepozycji oraz postpozycji wobec haj Jahwe. Partykula lim występuje w prepozycji bezpośredniej według wzoru lim haj Jahwe w tekstach liturgicznych wypowiadanych podczas uroczystości religijnych: Jr 5,$2 ; 16,15=23$, 8. Wzór przysięgi lim haj Jahwe odpowiada ugaryckiej przysiędze whm Aliyan blal (UT: $76:$ III : 2), która istnienie Baala stawiała pod znakiem zapytania używając partykuły warunkowej $h \mathrm{~m}$ w kontekście powracania do życia Baala.

Partykuła lim występuje w prepozycji pośredniej niestałej według wzoru - lim ... haj Jahwe - w następujących miejscach — 
Rut 3,$13 ; \operatorname{Jr} 4,2 ; 12,16 ; 44,26 ; \mathrm{Oz} 4$, 15. Partykuła lim występuje w postpozycji bezpośredniej w następujących miejscach według wzoru haj Jahwe lim: $1 \mathrm{Sm} \mathrm{14,45;19,6;28,} \mathrm{10;2} \mathrm{Sm} \mathrm{14,} \mathrm{11;} 1 \mathrm{Krl}$ 18,$10 ; 17,12 ; 2 \mathrm{Krl} 2,2.4 .6 ; 4,30$. Wymienione wiersze pochodzą z ksiąg historycznych oraz posiadają kontekst życia codziennego.

Partykula lim występuje w postpozycji pośredniej po haj Jahwe w następujących miejscach według wzoru haj Jahwe... I im: $1 \mathrm{Krl}$ 17, 1; $2 \mathrm{Krl} 3,14 ; 5,16$ : Jr 38, 16. Partykuła )im występująca w postpozycji pośredniej ma miejsce w przysięgach negatywnych, gdzie jedna osoba wobec drugiej wypowiada przysięge $\mathrm{w}$ formie uroczystej w sytuacjach krytycznych i bardzo wielkiej wagi, gdzie zachodzi bądź niebezpieczeństwo śmierci bądź chęć przebywania z osobą ukochaną na zawsze.

Wpływ religii kananejskiej a zwłaszcza ugaryckiej i fenickiej na religię izraelską zaznaczył się w tym, że partykuła )im występuje w prepozycji bezpośredniej (por. ugarycką przysięgę whm Aliyan $b(a l)$. Stąd też Izraelici typowe formuły kultowe zmieniali w duchu religii kananejskich, gdzie dominującym bóstwem był Baal bóg wegetacji ${ }^{9}$.

Dlatego to prorok Jeremiasz zabrania wypowiadać kłamliwie przysięgę haj Jahwe, która sugerowałaby względność istnienia Jahwe. Również antybaalistyczne przepowiadanie proroków Ozeasza i Eliasza spowodowało fakt występowania partykuły lim w prepozycji pośredniej haj Jahwe w kontekście życia codziennego i w kulcie.

Dalszym osłabieniem religii kananejskiej jest postpozycja bezpośrednia i pośrednia partykuły lim. Przysięga haj Jahwe z postpozycją bezpośrednią partykuły lim była stosowana w sytuacjach, kiedy osoba zwracała się do osoby, bądź też kiedy naród zwracal się do króla (1 Sm 14, 45). Wypowiadana w tej formie nie stawiała problemu istnienia Jahwe pod znakiem zapytania, lecz przeciwnie w oparciu o dynamiczne i nieograniczone czasem życie Jahwe była rękojmią spełnienia się warunku, jaki zawierała. Również przysięga haj Jahwe z partykułą lim w postpozycji pośredniej występowala w kontekście życia codziennego.

Oprócz partykuły wyodrębniającej lim spotykamy partykułę warunkową lû, która występuje jeden $\mathrm{raz} \mathrm{w} \operatorname{Sdz} 8,19 \mathrm{w}$ postpozycji bezpośredniej i służy dla podkreślenia warunku nierzeczywistego ${ }^{10}$.

9 Por. C. J. Labus change, The incomparability of Jahweh in the Old Testament (Pretoria Oriental series, vol. V), Leiden 1966, s. 117. T. W orden, The Literary Influence of the Ugaritic Fertility Myth on the old Testament, VT 3 (1953) 290.

10 P. J oüon, Grammaire de l'hébreu biblique, Rome 1923, § 167f. 
B. Inne partykuly i zaimek względny.

Do innych partykuł zaliczamy - lim, kî lim, 'al, kî, lûlê. Partykuła Iim nie pełniąca funkcji wyodrębniającej, występuje w Rut 3, 13; $2 \mathrm{Krl} 3$, 14; Jr 38, 16 w roli partykuły rozłącznej Rut 3, 13 prepozycja pośrednia, $2 \mathrm{Krl} 3$, 14; Jr 38, 16 - postpozycja pośrednia.

Partykuła $k \hat{\imath}$ lim występuje trzykrotnie w przysięgach negatywnych, a mianowicie w $1 \mathrm{Krl} 17,1.12 ; 1 \mathrm{Sm} \mathrm{14,45}$ po partykule wyodrębniającej lim, aby rozpocząc zdanie afirmatwne. Partykuła $k \hat{\imath}$ ) $i m$ występuje w przysięgach celem nadania pewności, że to co w przysiędze jest wypowiadane niechybnie się stanie. (Postpozycja

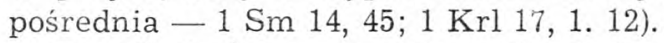

Partykuła 'al występuje w $\mathrm{Oz} 4,15$ w prepozycji pośredniej celem umożliwienia wyliczania. Partykuła $k \hat{\imath}$ pojawia się dwukrotnie,

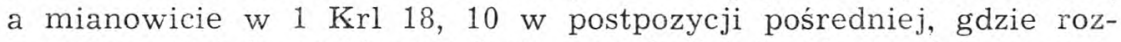
poczyna ostatnią część przysięgi; a w $2 \mathrm{Krl} 3,14$ również w postpozycji pośredniej, gdzie poprzedza bezpośrednio partykułę warunkową lûlê, która służy do wyrażania warunków nierzeczywistych w zdaniach warunkowych. Zaimek względny lašer występuje czterokrotnie w przysieggach negatywnych w $2 \mathrm{Krl} 3,14 ; 5,16 ; 1 \mathrm{Krl}$ 17,1 ; Jr $16,15=\mathrm{Jr} 23,8 \mathrm{w}$ postpozycji bezpośredniej rozpoczynając zdanie względne. W wymienionych wierszach zdanie względne zaczynające się od lašer służy do ukazania specjalnej relacji, jaka zachodzi między Jahwe a prorokiem. W $1 \mathrm{Krl}$ 18, 10 zaimek względny lašer występuje w postpozycji pośredniej po haj Jahwe, gdzie rozpoczyna zdanie względne podkreślające stanowczość rozkazu Achaba mającego na celu bezzwłoczne odszukanie Elizeusza.

Obok zaimka względnego lašer występuje jeden raz zaimeik względny $k a^{\prime} a s_{e}$ w Jr 12,16 w postpozycji bezpośredniej dla podkreślenia różnicy między przysięgą haj Jahwe a przysięgą na Baala.

\section{Przysiegi pozytywne}

\section{A. Partykuly wyodrębniajace.}

W przysięgach pozytywnych rolę partykuł wyodrębniających peł-

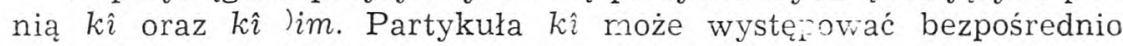
przed lub po haj Jahwe. Partykuła kî występuje w prepozycji bezpośredniej wobec haj Jahwe w 1 Sm 14, 39.

Partykuła kî występuje w postpozycji bezpośredniej w następujących miejscach: $1 \mathrm{Sm} 20,3 ; 26,16 ; 29,6 ; 2 \mathrm{Sm} 12,5 ; 15,21 ; 1 \mathrm{Krl}$ 22, 14; $2 \operatorname{Krn~18,~13;~} 1 \mathrm{Sm} \mathrm{25,34.}$

Partykuła kî występuje po haj Jahwe w postpozycji pośredniej w: $2 \mathrm{Sm} \mathrm{4,} \mathrm{9;} 1 \mathrm{Krl} 1,29-30 ; 2,24 ; 18,15 ; \mathrm{Jr} 16,4=\mathrm{Jr} 23,7$.

Najliczniej jest reprezentowana grupa haj Jahwe kî $z$ uwagi na specjalne zaakcentowanie trwałości życia Jahwe. W przysięgach ba- 
alistycznych spotykamy typ $k \hat{\imath}$ hy aliyan blal (UT 49: III: 20) występujący w poemacie o Baalu i Mocie, wskazującym na względność życia Baala jako boga wegetacji, który stosownie do pór roku regularnie umiera i zmartwychwstaje. Jedyny raz wystepujący związek kî haj Jahwe w $1 \mathrm{Sm}$ 14, 39 jest paralelą do ugaryckiej przysięgi na życie Baala.

Aby zatrzeć wszelkie ślady podobieństwa do przysiąg baalistycznych partykułę kî przesunięto o kilka wyrazów dalej po haj Jahwe. $\mathrm{Na}$ pierwsze miejsce po haj Jahwe wystawiono zdanie względne zaczynające się od zaimka względnego lašer (2 Sm 4, 9; $1 \mathrm{Krl} 1$, 29$30 ; 2,24 ; 18,15)$ a partykułę $k \hat{\imath}$ stosowano dopiero po zdaniu względnym określającym czyny Jahwe dokonane dla dobra jednostki. W ten sposób przełamano całkowicie wpływ kultu Baala.

Drugą partykułą wyodrębniającą stosowaną w przysięgach pozytywnych jest partykuła $k \hat{\imath}$ lim, która występuje dwukrotnie w postpozycji bezpośredniej wobec haj Jahwe w 1 Sm 26, 10; 2 Krl 5, 20.

Jak widzimy postpozycja czy też prepozycja partykuł pozostają nośnikami tendencji teologicznych ukazujących rozwój wiary Izraela w Starym Testamencie.

Żmigród

KS. JERZY WOŹNIAK CM

\section{Ks. Józef Kudasiewicz}

\section{SLOWO JEZUSA PEKNE MOCY}

(Homilia na XVII Sympozjum polskich biblistów w Nysie)

Zdumiewali się Jego nauka, gdyż stowo Jego było petne mocy (Ek 4, 32).

Ewangelia dzisiejszej liturgii (Łk 4, 31-37) mówiąca o słowie Jezusa pełnym mocy, o słowie budzącym zdumienie i znaki zapytania, harmonizuje doskonale $\mathrm{z}$ naszymi rozważaniami i dyskusjami naukowymi na temat słowa Bożego w pierwotnym Kościele.

To świadectwo dzisiejszej Ewangelii o słowie Jezusa jest szczególnie cenne, ponieważ otrzymujemy je od św. Łukasza - pierwszego historyka pierwotnego Kościoła. Opis dziejów Kościoła i jego misji głoszenia słowa Bożego Żydom i poganom poprzedził Łukasz, ,pierwszym słowem” (prõtos logos), w którym napisał o wszystkim, co Jezus czynit $i$ nauczat od początku aż do dnia, w którym udzielił przez Ducha Swiętego poleceń apostołom... (Dz 1, 1n). Dla Łukasza, u początków Kościoła, przed kerygmatem i didache Apostołów było słowo i czyn Jezusa. To słowo Jezusa jest fundamentem i modelem dla głosicieli słowa w Kościele. 